\title{
Assessment of pastoral vulnerability and its impacts on socio-economy of herding community and formulation of adaptation options
}

Balt Suvdantsetseg a ${ }^{\text {* }}$, Bolor Kherlenbayar ${ }^{\mathrm{b}}$, Khurel Nominbolor ${ }^{\mathrm{c}}$, Myagmarsuren Altanbagana ${ }^{\mathrm{b}}$, Wanglin Yan ${ }^{\mathrm{d}}$, Toshiya Okuro ${ }^{\mathrm{e}}$, Togtokh Chuluun ${ }^{\mathrm{f}}$, Takafumi Miyasaka ${ }^{\mathrm{g}}$, Shaokun Wang ${ }^{\mathrm{h}}$, and Xueyong Zhao ${ }^{\mathrm{h}}$

a Sustainable Development Institute for Western Region of Mongolia, Ulaanbaatar, Mongolia

$b$ Institute of Geography and Geoecology, Ulaanbaatar, Mongolia

c Institute for Strategic Studies, Ulaanbaatar, Mongolia

d Keio university, Kanagawa, Japan

e The University of Tokyo, Tokyo, Japan

$f$ Sustainable Development Institute, Ulaanbaatar, Mongolia

$g$ Nagoya University, Nagoya, Japan

${ }^{h}$ Northwest Institute of Eco-Environment and Resources, Lanzhou, China

* Corresponding author. Email: suvd16@gmail.com

\section{ABSTRACT}

Rangelands located in arid and semi-arid regions are particularly vulnerable to climate change. The objective of this research project is to assess vulnerability and its impacts on socio-economy of pastoral society and to formulate adaptation options for the selected rangelands. The analysis process consisted of (1) using geospatial techniques to assess the pastoral vulnerability; (2) using statistical correlation analysis to assess the impact of vulnerability on the grazing societies' socio-economic conditions; (3) using qualitative document analysis (QDA) to evaluate policy documents; and (4) engaging in policy formulation, which included active participation by multiple academic researchers, policymakers, and representatives of the local community. The pastoral vulnerability assessment results reveal that drought, pasture usage and normalized difference vegetation index are the main drivers of vulnerability. Pastoral vulnerability increases the breeding stock's miscarriage rate and causes livestock loss, which may affect the socio-economics of the herder community, devaluing herders' labour and shortening their life expectancy. Two provinces' policies were reviewed, and the findings suggest that aligning development and sectoral policies with climate change responses (i.e. adaptation and mitigation) to enhance the adaptive and transformative capacity of rural communities is important. The adaptation options and policy recommendations for two provinces are identified to enhance the resilience of livelihoods to climate change to potentially reduce vulnerability to anthropogenic climate change and advance development.

\section{KEYWORDS \\ Adaptation strategy, life expectancy, livestock, pastoral vulnerability, socio-economy}

\section{DOI}

https://doi.org/10.30852/sb.2020.1107

\section{DATES}

Received: 1 November 2019

Published (online): 11 September 2020

Published (PDF): 20 October 2020

Tc)
Attribution-NonCommercial 4.0 International License.
HIGHLIGHTS
Consecutive years of pastoral
vulnerability resulted in
lesser fat in the livestock and
decreased ability to overcome
disaster risks.
Pastoral vulnerability strongly
affected the female goats'
miscarriage rate in the two
provinces studied.
Men in the Gobi-Altai
province were more sensitive
to pastoral vulnerability,
which should be taken into
account when considering
future implications.
Adaptation policies that
integrate sustainable
development and climate
change mitigation are needed.




\section{INTRODUCTION}

\subsection{Background}

The socio-ecological system in a non-equilibrium environment is most vulnerable to changes in climate and land-use activities (Okuro, 2019). Nomadic pastoralism is a complex human-environmental system practised in Mongolia that includes livestock, grazing pastures, and a herding society, which are interdependent (Togtokh, Altanbagana, Davaanyam, Tserenchunt \& Ojima, 2014). Traditionally, nomadic pastoralists have actively managed their use of grazing land to preserve ecosystem resources (Fernandez-Gimenez, Baival, Batjav \& Ulambayar, 2015).

Mongolia is an agriculture-based country where pastoral livestock production contributes $10.52 \%$ of the country's GDP, uses $72.1 \%$ of its total land area, and employs $21.6 \%$ of its total workforce. The western region of Mongolia is a non-equilibrium environment (Illius \& Connor, 1999), which is arid and experiences highly variable weather (Gomboluudev,2019). The social systems in these regions predominantly depend on pastoral grazing labour. As they typically employ traditional grazing strategies that are opportunistic and nomadic, risk reduction management and climate adaptation plans or strategies have not been officially formulated, which may lead to further environmental risks.

Vulnerability is defined as a combination of the degree of exposure (stressors) and sensitivity (Adger, 2006) of social-ecological systems under natural and human impacts and the adaptive capacity by mitigating and coping responses to new opportunities (Turner et al., 2003). Vulnerability to pastoralism in this study is explained through natural stressors of drought (Ojima, Togtokh, \& Altanbagana, 2014), and human factors of pasture use and vegetation cover change as a set of linked impacts on social and economic conditions and coping strategies of herder communities in responding to these stresses.

Pastoral vulnerability causes a reduction in or loss of livelihood quality (Adger, 2006), economic productivity due to climate pressures (Troy, 2015) and over-grazing. Most of the studies of pastoral ecological vulnerability in Mongolia have focused on droughts or "dzud disasters" (Togtokh, Altanbagana, Ojima, \& Suvdantsetseg, 2017; Natsagdorj, 2009; Reynolds et al., 2007). Dzud is a Mongolian term for severe winter weather and is associated with livestock deaths. Preventing dzud disasters is vital; however, the pastoral ecosystem's vulnerability is also an important issue (Shinoda, Nandintsetseg, \& Erdenetsetseg, 2018). Instead, inadequate pasture and disaster risk management and the number of livestock animals (Nandintsetseg, Shinoda, Du \& Munkhjargal, 2018), as well as aridity and precipitation levels during growing seasons, have the most significant impact on the regions' socio-ecological vulnerability.

Due to rapid increases in the number of livestock animals and climate change, the degradation of pasture land has increased to 70\% (Asian Development Bank [ADB] \& Ministry of Environment and Green Development [MED], 2014). The pasture yield has fallen by $20 \%$ to $30 \%$ in almost all regions in Mongolia and the pasture carrying capacity has dropped by $20 \%$, further reducing the sustainability of nomadic animal husbandry (Bolortsetseg, Erdenetsetseg, \& Bat-Oyun, 2002). Researchers studying climate change adaptation (Adger, 2006; Armitage, 2005) state that there is a need to consider linkages between ecosystem services supporting sustainable livelihoods in the local community through its primary products and services, and local communities' adaptive capability on the ecosystem. To effectively align adaptation policies and prioritize implementation measures, policymakers require comprehensive information obtained via vulnerability assessments of regions and various sectors (Preston, Yuen, \& Westaway, 2011; O'Brien et al., 2004). To prevent the harm of pasture degradation induced by climate change and human activity, the assessment of pastoral grazing vulnerability and its impacts on the socio-economics of local communities and effective adaptive mechanisms are urgently needed. Therefore, adapting traditional pastoralism to address climate change in the vulnerable, arid regions is challenging, but it is important for sustainable pasture use, pasture management planning, and the effective implementation of adaptive measures.

\subsection{Objectives}

The main objective of this research project is to assess pastoral socio-ecological vulnerability and formulate adaptation strategies for the selected regions' grazing societies using a participatory approach. The specific goals are as follows:

» assess the pastoral ecological vulnerability of the two case areas;

» assess the impact of vulnerability for socio-economics of grazing society;

» evaluate current policy documents; and

» formulate adaptation strategies.

\section{METHODOLOGY}

\subsection{Research area}

The two nomadic pastoralism-based provinces selected for the study are Gobi-Altai and Khovd, which 
are located in western Mongolia. These areas are most affected by climate change-related disasters, such as dzud (Davaadorj, Erdenetsetseg, Elbegjargal, \& Oyunjargal, 2017), and drought (Batnasan, 2003). They have a highly vulnerable ecosystem and the largest percentage of out-migration, and have undergone significant cultural changes while attempting to retain the regions' nomadic rangeland systems, which are adversely affected by overgrazing in the Gobi Desert ecological region (Suvdantsetseg, Oba, Yan, \& Myagmarsuren, 2017).

Gobi-Altai province is the second-largest province in Mongolia in terms of territory; it covers a total area of $141,100 \mathrm{~km}^{2}$, and the elevation ranges from $1,000-3,802$ $\mathrm{m}$ above sea level. The annual average precipitation is $80-135 \mathrm{~mm}$, and most of the rainfall occurs during the summer season. This province consists of 18 administrative units (soums) and about 3.5 million sheltered livestock (NSOM, 2018). The livestock sector generates $43.8 \%$ of the province's GDP. By 2018, the population had reached 58,400 , decreasing by $18.4 \%$ since 1998 , and $21 \%$ of the total population are herders, totalling 16,711 householders, $66.6 \%$ of whom live in rural areas and practice nomadic herding.

Khovd province covers a $76,100 \mathrm{~km}^{2}$ area lying in Mongolia's Altai mountain range and Great Lakes Depression, where the altitude ranges from $1000-4200$ $\mathrm{m}$. The annual average precipitation is $50-300 \mathrm{~mm}$, and the annual average air temperature is $-0.3^{\circ} \mathrm{C}$. This province has a population of 87,300 people, which has decreased by $3.8 \%$ since $1998 ; 74 \%$ of the rural population in 16 soums are living in grazing areas, and $26 \%$ of them live in soum (town) centres (NSOM, 2018). Most $(67 \%)$ of the land is used for agriculture (Munkhdulam, Avirmed, Jonathan \& Renchinmyadag, 2018), pasturing about 6.8 million livestock and generating $36.9 \%$ of Mongolia's GDP.

\subsection{Data sources used}

This project used statistical, observational, meteorological, field survey, and remote sensing data covering the period of 1998-2017, collected from various sources. A brief description of the data is provided in Table 1. Our two teams collected the field survey data during field visits. One of the field surveys was performed in two sub-provinces from 16 July 2018 to 5 August 2018, which were selected because they are most vulnerable in terms of pasture degradation based on an initial pasture ecological vulnerability assessment of two provinces. Based on the research results, the collaborators decided to identify the main reasons and conditions of the grassland changes, including changes in vegetation types and the degradation of grassland biomass and volumes, by comparing field survey and map data collected in 1981 and 2018. The qualitative data were collected during field visits conducted from 19-29 July 2019 via focus group discussions for policy-scenario development purposes. The reviewed policy documents were obtained from local government offices in the two provinces.

\subsection{Methods}

The general framework of the project applied a combination of geo-visualization techniques and a participatory approach for all levels of data collection, integrating method development and assessment, as well as policy-scenario development during group meetings, training and discussion workshops, and documents review. The analysis process consisted of (1) using geospatial techniques to assess the pastoral vulnerability; (2) using statistical correlation analysis to assess the impact of vulnerability on the grazing societies' socio-economic conditions; (3) using qualitative document analysis (QDA) to evaluate policy documents; and (4) engaging in policy formulation, which included active participation by multiple academic researchers, policymakers, and residents of the local community.

\subsubsection{Assessment of pastoral vulnerability}

The socio-ecological vulnerability assessment (Togtokh, Altanbagana, Ojima, \& Suvdantsetseg, 2017) was modified for use in the ecological vulnerability assessment of pasture lands (Equation 1). Multivariate statistical analysis (Hidalgo \& Goodman, 2013), as well as weighted summation analysis for rescaling different index values, were applied to the data. The main driving measures of pastoral vulnerability were identified as drought, pasture use, and normalized difference vegetation index (NDVI); see Equation 1 below:

$$
V_{t, i}^{e c o}=\frac{\frac{\Delta S_{t, i}^{\text {norm }}+\Delta N_{t, i}^{\text {norm }}}{2}+V g_{t, i}^{\text {norm }}}{2}
$$

Here, $V_{t, i}^{e c o}$ is pastoral vulnerability, while $\Delta S_{t, i}^{\text {norm }}$ refers to the normalized drought index, $\Delta N_{t, i}^{n o r m}$ refers to the normalized pasture use index, and $V g_{t, i}^{\text {norm }}$ refers to the normalized difference vegetation index.

The drought index was calculated using the Ped's index, which represents climate variability (Natsagdorj, 2009). The pasture lands' carrying capacity, which was determined at the soum level by the Mongolian government (Mongolian Academy of Sciences, 1990), was used for the threshold value of pasture use. Pasture use index (Tserendash \& Bilegt, 2017) was modified to calculate the pasture use for the pastoral vulnerability assessment. The NDVI indicates the density of green vegetation (Weier \& 


\begin{tabular}{|l|l|}
\hline \multicolumn{2}{|l|}{} \\
\hline No & Name of data \\
\hline 1. & Livestock \\
\hline 2. & Livestock by type \\
\hline 3. & Livestock loss by type \\
\hline 4. & Barren female animals by type \\
\hline 5. & Miscarriage female animals by type \\
\hline 6. & Breeding stock by type \\
\hline 7. & Migration \\
\hline 8. & Poverty rate \\
\hline 9. & Life expectancy \\
\hline 10. & Well \\
\hline 11. & Cereals \\
\hline 12. & Potatoes \\
\hline 13. & Vegetables \\
\hline 14. & Fodder crops \\
\hline 15. & Insured livestock \\
\hline 16. & Insured households \\
\hline 17. & Bank loan \\
\hline 18. & Bank deposit \\
\hline 19. & Herder household \\
\hline & \\
\hline 1.90
\end{tabular}

Statistical

\begin{tabular}{|c|c|c|c|}
\hline Time range & Units & Spatial range & Source \\
\hline 1998-2017 & Number & All soums & NSOM \\
\hline $1998-2017$ & Number & All soums & NSOM \\
\hline $1998-2018$ & Number & All soums & NSOM \\
\hline $1998-2018$ & Number & All soums & NSOM \\
\hline 1998-2018 & Number & All soums & NSOM \\
\hline $1999-2018$ & Number & All soums & NSOM \\
\hline $1990-2018$ & Number & Province & NSOM \\
\hline 2010 & Percentage & All soums & NSOM \\
\hline 1998-2017 & Number & Province & NSOM \\
\hline $2012,2015,2018$ & Number & All soums & NSOM \\
\hline $2000-2018$ & Ton & All soums & NSOM \\
\hline $2000-2018$ & Ton & All soums & NSOM \\
\hline $2000-2018$ & Ton & All soums & NSOM \\
\hline $2000-2018$ & Ton & All soums & NSOM \\
\hline $2010-2018$ & Number & All soums & NSOM \\
\hline $2010-2018$ & Number & All soums & NSOM \\
\hline $2010-2018$ & Tugrug & All soums & NSOM \\
\hline $2010-2018$ & Tugrug & All soums & NSOM \\
\hline $2012-2018$ & Number & All soums & NSOM \\
\hline
\end{tabular}

Meteorological observation

\begin{tabular}{|c|c|c|c|c|c|}
\hline No & Name of data & Time range & Units & Spatial range & Source \\
\hline 2. & Precipitation & 1970-2017 Monthly & $\mathrm{Mm}$ & All soums & NAMEM \\
\hline 3. & Pastoral area & 1990 & Hectare & All soums & NAM \\
\hline 4. & Pasture carrying capacity & 1990 & $\begin{array}{l}\text { Sheep/per } \\
\text { hectare }\end{array}$ & All soums & NAM \\
\hline
\end{tabular}

Raster

\begin{tabular}{|l|l|l|l|l|l|l|}
\hline No & Satellite name & Product name & Time range & Units & Spatial range & Source \\
\hline 1. & SPOT VEGE & $\begin{array}{l}\text { NDVI data 2nd ten } \\
\text { days of August }\end{array}$ & $1998-2000$ & $1 \mathrm{~km}$ & 2 provinces \\
\hline 2. & eMODIS & $\begin{array}{l}\text { NDVI data 2nd ten } \\
\text { days of August }\end{array}$ & $2001-2017$ & $250 \mathrm{~m}$ & 2 provinces & https://earthexplorer.usgs.gov/ \\
\hline
\end{tabular}

Field survey

\begin{tabular}{|l|l|l|l|l|l|}
\hline No & Name of data & Date & Unit & Number of sites & Sampling size \\
\hline 1. & Biomass data & $\begin{array}{l}\text { 16 July to 5 August } \\
2018\end{array}$ & Hectare & 103 & $1 \mathrm{~m}$ x1m \\
\hline \multicolumn{2}{|c|}{ Document reviewed } \\
\hline
\end{tabular}

\begin{tabular}{|l|l|l|l|l|}
\hline No & Name of data & Implementation period & Policy area & Implementing area \\
\hline 1. & Comprehensive development policy & $2012-2020$ & Development & Gobi-Altai province \\
\hline 2. & Governor's Action Program & $2016-2020$ & Development & Gobi-Altai province \\
\hline 3. & Pasture management program & $2012-2020$ & Land \& Environment & Land \& Environment \\
\hline 4. & Sub-program to combat desertification & $2012-2020$ & Land \& Environment & Gobi-Altai province \\
\hline 5. & Environmental master plan & $2012-2020$ & Development & Gobi-Altai province \\
\hline 6. & Development strategy & $2015-2020$ & Development & Khovd province \\
\hline 7. & Green development policy & $2016-2026$ & Levelopment & Khovd province \\
\hline 8. & Governor's Action Program & $2016-2020$ & Khovd province & \\
\hline 9. & Pasture use improvement program & & \\
\hline
\end{tabular}

TABLE 1. Brief description of data used for selected areas. NSOM: National Statistics Office of Mongolia; NAMEM: National Agency of Meteorological and Environmental Monitoring; NAM: National Atlas of Mongolia. * The five types of livestock are horse, cattle, camels, sheep and goats. 
Herring, 2000) and the biomass of vegetation changes (Miyasaka, Okura, Zhao, \& Takeuchi, 2016). NDVI values, by themselves, do not provide sufficient information to conduct a pastoral vulnerability assessment. Therefore, we considered both multiyear average NDVI values and the coefficient of the linear trend equation of NDVI changes for the last 20 years to express trends in vegetation changes. Alternatively, the degraded grazing area was calculated to determine whether it exceeded the threshold value of vegetation vulnerability for each pixel. The threshold value of vegetation vulnerability was selected by the difference of the mean value and the standard deviation in the biomass peak time data derived from satellite images from 1999-2017 and determined for each pixel. Based on the results of this analysis, we selected two sub-provinces (Biger in Gobi-Altai province and Chandmani in Khovd province) for the detailed pasture change and vegetation surveys.

The threshold values of each indicator were applied to determine pastoral vulnerability in the case areas. Variables exceeding the threshold value were assumed to be the baseline for pastoral vulnerability. To combine individual indicators into an integrated pastoral vulnerability index, variables were calculated into the same range, from 0.0-1.0, by rescaling the weighted summation of values for long-term data.

\subsubsection{Correlation analysis of pastoral vulnerability on} socio-economics of grazing society

In this part of the study, we assessed the impacts of pastoral vulnerability on the socio-economic variables of selected pastoral communities. When examining a pastoral socio-ecological system, it is important to examine how pastoral ecosystem is vulnerable to human- and climate-induced change, including which areas are most affected and which indicators are more sensitive to the effects on the herders' socio-economic condition. Pearson correlation analysis (Lane, 2019) was applied to measure the strength of the relationships among variables. We performed a correlation analysis using 19 social, economic, and environmental indicators. The most significant results of this analysis, miscarriage rates among breeding stock in the livestock sector, and human life expectancy in the pastoral society are discussed in this paper.

\subsubsection{Evaluation of policy documents}

This part of the study used QDA to understand the extent to which the policy documents of two provinces, Khovd and Gobi-Altai, incorporate climate change and sustainable development giving an emphasis on pastoral societies and livestock sector. The QDA process uses subjective scoring, and we ensured consistency by following specific steps to perform an in-depth analysis: (i) collecting documents, (ii) identifying the main areas of analysis, (iii) coding the documents, and (iv) analysing findings. The synergy informed the building blocks for the QDA of climate change adaptation, mitigation responses, and sustainable development (Nhuan, 2019): climate adaptation, mitigation, and transforming capacity. Appropriate indicators for the building blocks were selected based on the SDGs aligned with Mongolia's National Green Development Policy and Sustainable Development Vision 2030 (SDV). For climate adaptation in terms of social resilience, the indicators included income diversification and poverty reduction (SDG 1), health and wellbeing of pastoral societies (SDG 3), water and sanitation including sustainable water management (SDG 6), and full and productive employment that are connected to pastoral livestock-keeping and sustainable tourism development (SDG 8). Other indicators of adaptation in terms of enhancing natural resilience included the sustainable land and pasture management and protection of pastoral ecosystems, combating desertification, and biodiversity conservation (SDG 15). Indicators of mitigation included reducing GHG emissions and encouraging renewable energy (SDG 7). For transforming capacity, we adopted indicators such as quality education and vocational skill development for herders (SDG 4), improved infrastructure including road networks to have access to markets and enabling services (SDG 9), and capacity building on adaptation to climate change, natural disaster and risk prevention (SDG 13).

A scoring system was developed based on the work of Gouais and Wach (2013) (Table 2). To determine the extent to which the policy documents align with the "building blocks", each of the policy documents was analysed separately. All assessments of alignment were supported by explanations and quotes from the policy to ensure rationale for each assessment.

\subsubsection{Development of policy recommendations}

After the three parts assessment, we organized several group meetings with academic researchers and collaborators, as well as three focus group meetings and two workshops that included multi-stakeholders from herding groups, academics, civil societies, and local, provincial, and national governors. The group meetings aimed to identify the key indicators of pastoral vulnerability, main factors affecting the herding communities, major barriers to adaptation and the lack of strategies to address them in the policy documents, and ways to successfully resolve these issues from the academic perspective. In these meetings, all of our research collaborators participated and presented findings and outputs of research via the Internet and face-to-face. Three 


\begin{tabular}{|l|l|l|}
\hline $\begin{array}{l}\text { Type of } \\
\text { alignment }\end{array}$ & Description of alignment & Score \\
\hline $\begin{array}{l}\text { High } \\
\text { alignment }\end{array}$ & $\begin{array}{l}\text { The policy aligns strongly with the } \\
\text { indicators of adaptation, mitigation } \\
\text { and transforming capacity (A/M/ } \\
\text { Tc). Policy devotes attention to the } \\
\text { particular building block and includes } \\
\text { specific activities for achieving the } \\
\text { particular block. }\end{array}$ & 3 \\
\hline $\begin{array}{l}\text { Partial } \\
\text { alignment }\end{array}$ & $\begin{array}{l}\text { Although the policy supports the } \\
\text { various indicators of A/M/Tc, it is less } \\
\text { clear in terms of how the indicators and } \\
\text { each particular building block could } \\
\text { be achieved. There is limited evidence } \\
\text { present of how the specific indicators } \\
\text { as well as the building blocks could be } \\
\text { achieved in practice. }\end{array}$ & 2 \\
\hline $\begin{array}{l}\text { Limited } \\
\text { alignment }\end{array}$ & $\begin{array}{l}\text { The policy supports a particular } \\
\text { indicator of the A/M/Tc building } \\
\text { block but there is a lack of evidence to } \\
\text { support alignment with it. }\end{array}$ & 1 \\
\hline $\begin{array}{l}\text { No } \\
\text { alignment }\end{array}$ & $\begin{array}{l}\text { There is no evidence in the document } \\
\text { to suggest that the policy supports the } \\
\text { implementation of the building block } \\
\text { or even encourages it. }\end{array}$ & 0 \\
\hline
\end{tabular}

TABLE 2. Scoring criteria for alignment of the policy documents with the building blocks (modified from Gouais \& Wach, 2013)

participatory focus group discussions were organized in the local project areas (the Biger soum and province center of Gobi-Altai province and the Zereg soum of Khovd province) from 19-30 July 2019. The group discussions covered various issues, including increasing pasture land degradation from the locals' viewpoint and lived experiences, the visible impacts of pastoral vulnerability on their livelihoods, and barriers to formulating and implementing policy documents. Finally, a participatory workshop entitled the 2nd Workshop on Socio-ecological Systems Governance for Sustainability was organized in Ulaanbaatar, Mongolia, from 23-24
August 2019 to conclude this part of the research and discuss policy recommendations.

\section{RESULTS AND DISCUSSION}

\subsection{Pastoral vulnerability analysis}

Two case areas' levels of pastoral vulnerability over the past two decades are presented in Figure 1. On the map, base colours reflect the level of pastoral vulnerability, and the graph shows the average value of components in each soum over the past two decades. The level of pastoral vulnerability in the two case areas is influenced by each of the three indicator values; the variable with the most significant impact is drought, followed by pasture use. Four soums in Gobi-Altai (Figure 1a) and five soums in Khovd (Figure 1b) were found to have the highest level of pastoral vulnerability based on climateand human activity-related impacts.

Table 3 presents the two case areas' level of vulnerability (i.e. high, moderate, and low) using three indicators: humans, livestock, and pasture area. Khovd province is at a high level of risk for people and livestock being affected, where human-related activities are the main driving forces in pastoral vulnerability. In GobiAltai province, climate change-related impacts are the main driving factors in pastoral vulnerability.

\subsection{Correlation analysis of pastoral vulnerability on the herding communities' socio-economic conditions}

\subsubsection{Livestock sector}

Pastoral vulnerability is a key factor in increased livestock miscarriage and loss, which may negatively impact the herders' income. Dzud is one of the main

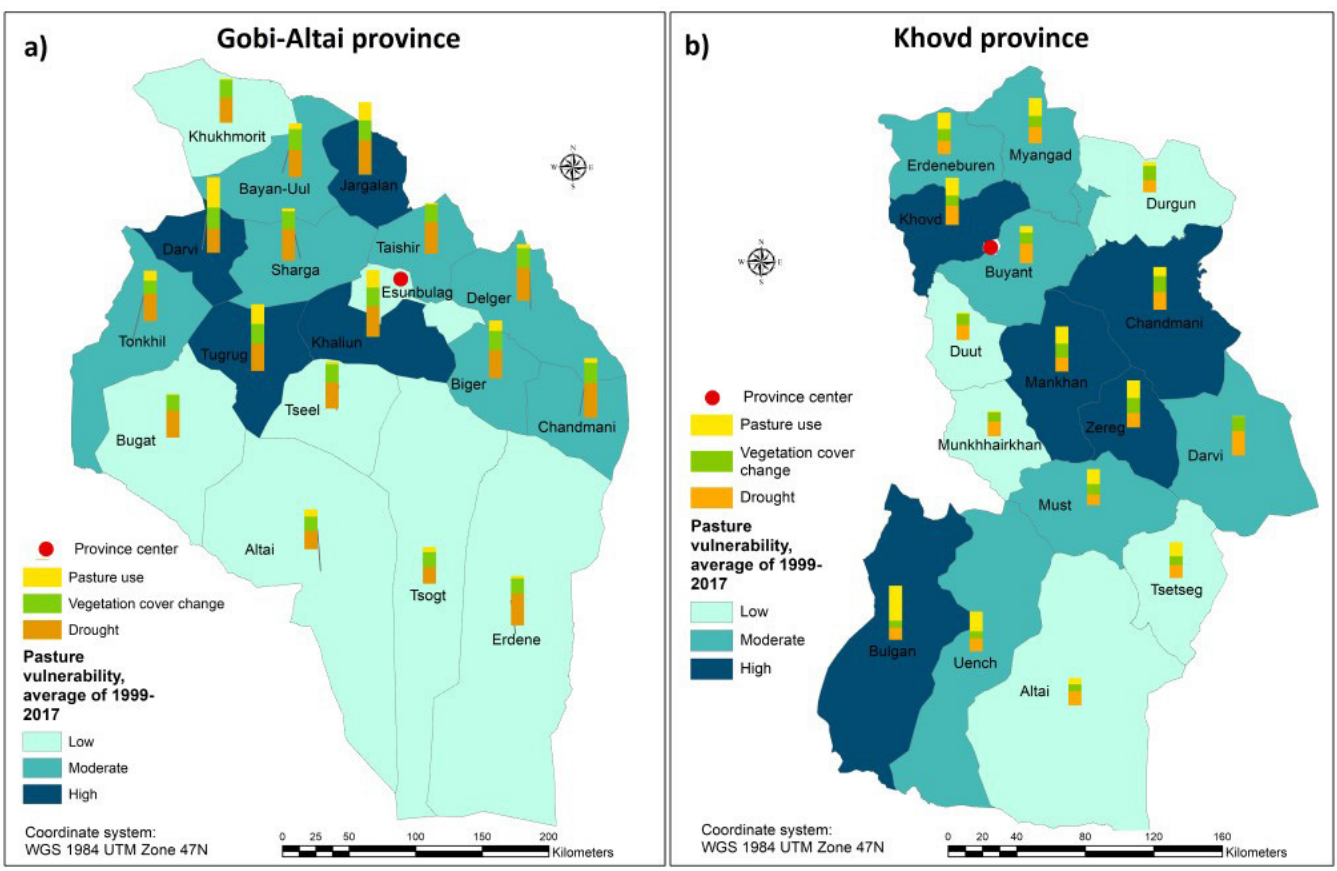

FIGURE 1. The pastoral vulnerability is high in mountain steppe region in Gobi-Altai province and desert and desert steppe regions in Khovd province. Main driving component indicators are climate-related drought in Gobi-Altai province and human- related pasture use in Khovd province. 


\begin{tabular}{|l|l|l|l|l|l|c|}
\hline \multirow{2}{*}{$\begin{array}{l}\text { Vulnerability } \\
\text { level }\end{array}$} & \multicolumn{2}{|c|}{ Gobi-Altai } & \multicolumn{3}{c|}{ Khovd } \\
\cline { 2 - 8 } & \multicolumn{1}{|c|}{ People \% } & Livestock \% & Pasture area \% & People \% & Livestock \% & Pasture area \% \\
\hline High & 14 & 20.8 & 12.6 & 27.6 & 35.1 & 31.5 \\
\hline Moderate & 28.4 & 39.8 & 26.8 & 56.8 & 23.7 & 33.4 \\
\hline Low & 57.5 & 39.4 & 60.6 & 15.5 & 41.2 & 35.1 \\
\hline
\end{tabular}

TABLE 3. Results of the ecological vulnerability assessment.

causes of livestock loss (Natsagdorj, 2009), but its impact is lower when compared to pastoral vulnerability. Livestock miscarriage and loss increased in the winter and spring months following years with high pastoral vulnerability (Figures $2 \mathrm{a}$ and $2 \mathrm{~b}$ ). High pastoral vulnerability for 2-3 consecutive years leads to insufficient fat intake in the livestock animals' diets during the summer months, negatively impacting their ability to survive during the upcoming cold winter months and, ultimately, increasing their mortality rates. In the years with low pastoral vulnerability, the number of livestock animals increased rapidly (Figure 2).

Statistical correlations were calculated for pastoral vulnerability and the miscarriage rate among breeding stock for four types of female animals (Table 4). High miscarriage rates devalue the herders' labour and reduce their income. In Gobi-Altai and Khovd provinces, $86 \%-98 \%$ and $83 \%-93 \%$, respectively, of the total livestock are small animals (i.e. sheep and goats); goats comprise $45 \%-76 \%$ of the total herd in Gobi-Altai and $37 \%-66 \%$ in Khovd province. The small livestock animals' miscarriage rates were more susceptible to pastoral vulnerability and were strongly correlated with female goats' miscarriage rates in the two provinces. However, no strong correlations were found for other herd types.

\subsubsection{Life expectancy of rural communities}

Over 18 years (2000-2018), the life expectancy of Gobi-Altai province's residents reached the national average, while in Khovd province, it surpassed the national average (Figure 3). In 2000, women lived on average 5 years longer than men in Gobi-Altai, and 6 years longer than men in Khovd province. In 2018, the difference was 9 years in Gobi-Altai and 6 years in Khovd. The average life expectancy of men living in Gobi-Altai increased by 5 years over the same period (2000-2018), while that of women increased by 10 years (Figure 3a); however, in Khovd province, the difference in life expectancy for men and women remained stable at 6 years (Figure 3b). These findings may be due to some lifestyle factors, such as living and working conditions and local cultural differences. Male herders are more affected by pastoral activities due to their working conditions in a harsh climate and the limited services provided by social systems in Gobi-Altai province. In 2008, the average life expectancy of men decreased from 61 to 59 compared to the previous year, while it dropped from 68 to 67 for their counterparts in Gobi-Altai. As for Khovd province, differences in life expectancy decreased for both groups, from 64 to 61 for men and from 71 to 70 for women. These numbers suggest that men are more sensitive to pastoral vulnerability. This result is an important issue, especially

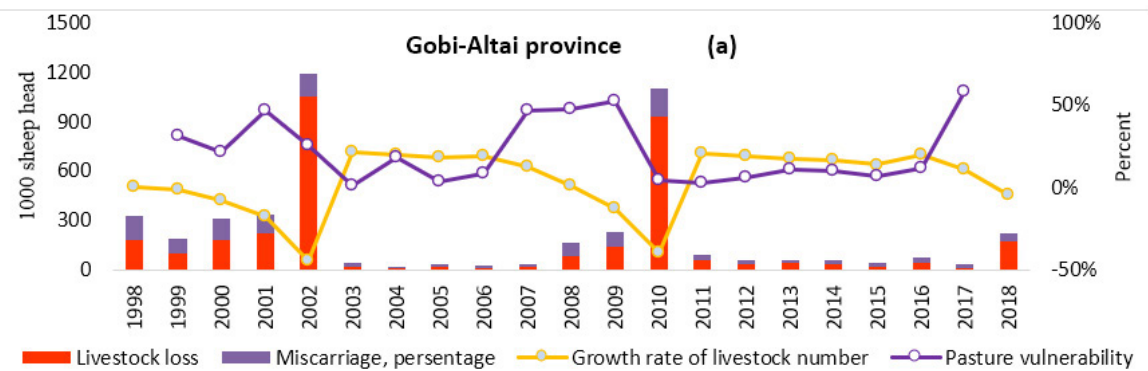

Khovd province

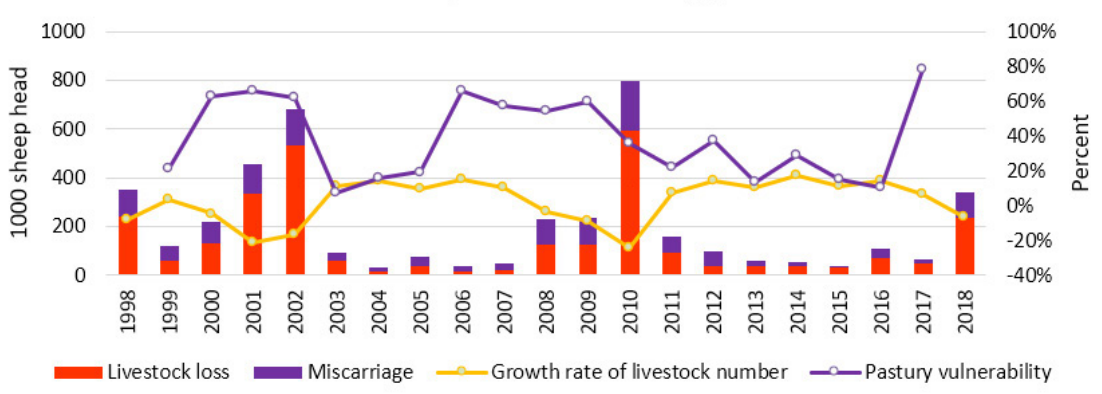

FIGURE 2. High pastoral vulnerability results in increased livestock miscarriage and loss, and decreased livestock growth rate. 


\begin{tabular}{|c|c|c|c|c|c|c|c|c|c|}
\hline Gobi-Altai province & Mare & Cows & $\begin{array}{l}\text { Female } \\
\text { sheep }\end{array}$ & $\begin{array}{l}\text { Female } \\
\text { goats }\end{array}$ & Khovd province & Mare & Cows & $\begin{array}{l}\text { Female } \\
\text { sheep }\end{array}$ & $\begin{array}{l}\text { Female } \\
\text { goats }\end{array}$ \\
\hline Delger & 0.29 & 0.47 & 0.41 & 0.28 & Darvi & -0.05 & 0.10 & -0.05 & 0.81 \\
\hline Taishir & 0.08 & 0.29 & 0.10 & 0.34 & Altai & 0.67 & 0.53 & 0.29 & 0.69 \\
\hline Tugrug & 0.17 & 0.43 & 0.27 & 0.37 & Zereg & 0.37 & -0.05 & 0.13 & 0.67 \\
\hline Chandmana & 0.50 & 0.26 & 0.49 & 0.50 & Chandmani & 0.34 & 0.16 & 0.37 & 0.65 \\
\hline Khukhmorit & 0.36 & 0.32 & 0.39 & 0.51 & Munkhkhairkhan & 0.20 & 0.41 & 0.64 & 0.61 \\
\hline Esunbulag & 0.50 & 0.13 & 0.63 & 0.53 & Bulgan & 0.34 & 0.28 & 0.29 & 0.61 \\
\hline Altai & 0.29 & 0.56 & 0.55 & 0.56 & Mankhan & 0.23 & 0.22 & 0.40 & 0.56 \\
\hline Dariv & 0.40 & 0.46 & 0.30 & 0.57 & Must & 0.27 & 0.20 & 0.22 & 0.50 \\
\hline Khaliun & 0.17 & 0.46 & 0.51 & 0.60 & Tsetseg & 0.69 & 0.52 & 0.17 & 0.46 \\
\hline Biger & 0.29 & 0.34 & 0.36 & 0.61 & Durgun & 0.40 & 0.38 & 0.41 & 0.40 \\
\hline Jargalan & 0.24 & 0.57 & 0.57 & 0.61 & Khovd & 0.22 & 0.07 & 0.13 & 0.37 \\
\hline Tsogt & 0.52 & 0.36 & 0.49 & 0.64 & Myangad & -0.12 & 0.23 & 0.41 & 0.33 \\
\hline Bayan-Uul & 0.07 & 0.25 & 0.37 & 0.68 & Duut & -0.16 & 0.16 & 0.19 & 0.27 \\
\hline Sharga & -0.04 & 0.31 & 0.58 & 0.68 & Buyan & 0.03 & 0.14 & 0.21 & 0.26 \\
\hline Erdene & 0.45 & 0.47 & 0.58 & 0.69 & Uench & 0.04 & 0.35 & 0.11 & 0.26 \\
\hline Tonkhil & 0.35 & 0.17 & 0.57 & 0.72 & Erdeneburen & -0.02 & 0.10 & 0.66 & 0.13 \\
\hline Tseel & 0.30 & 0.33 & 0.29 & 0.74 & & & & & \\
\hline Bugat & 0.29 & 0.62 & 0.74 & 0.86 & & & & & \\
\hline
\end{tabular}

TABLE 4. Correlation analysis of pastoral vulnerability and livestock miscarriage rates among different types of livestock in the two selected areas.

in Gobi-Altai province, as well as at the national level in terms of pension system policies related to men.

\subsection{Assessment of policy documents}

This part of the study assessed the extent to which policies in the economic development and environmental sectors align with climate change response (i.e. adaptation and mitigation) and sustainable development goals and identified varying levels of coherence amongst these policies in Gobi-Altai and Khovd provinces. After applying qualitative document analysis and content analysis to the policy documents, the findings suggest that the policies of these two provinces acknowledge climate change as a threat to the development in the western region.

In Gobi-Altai province, all the reviewed policies have "limited alignment" with climate change responses, particularly the inadequate adaptation measures adopted to strengthen social resilience. It implies that people are not well prepared for future changes, and the capacity remains low for dealing with adverse climate and environmental impacts. Gobi-Altai province has not updated its midterm development policy, or comprehensive development policy (CDP), under global SDGs and SDV-2030, and Mongolia's green development policy. This finding has implications for the province as it needs to formulate new policies to align climate change adaptation and sustainable development.
In Khovd province, the reviewed policy documents have "partial" and "limited alignment" as these contain climate change responses with good adaptation measures directed at enhancing natural resilience. Khovd province has developed and approved its midterm policies, provincial development strategy (DS), and green development policy (GrDP) following the new national policies. In Khovd province, human impacts, including the increased number of livestock animals, are equally important for pasture ecological vulnerability, requiring comprehensive policy measures directed at reducing pastoral vulnerability and promoting sustainable development.

The analysis of two provinces' policy documents indicates there is a need for well-aligned adaptation policies to enhance the resilience of their residents' livelihoods to climate change because climate change is seen as a development issue, and adaptation activities can potentially reduce vulnerability to climate and other variability and can advance economic development.

\subsection{Adaptation options}

A final workshop was organized from 23-24 August 2019 at the Mongolian Academy of Sciences in Ulaanbaatar to conclude the research outputs and identify potential adaptation options to reduce pastoral vulnerability in the selected areas. The participants included academic research members from all collaborating 


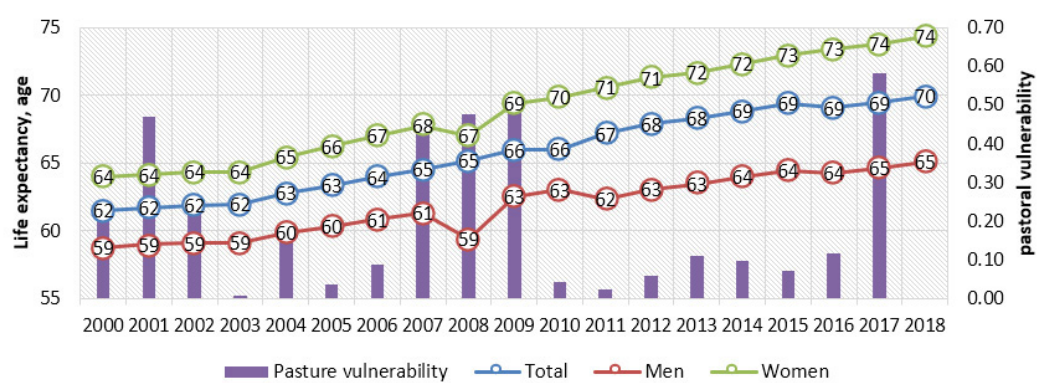

Khovd province

(b)

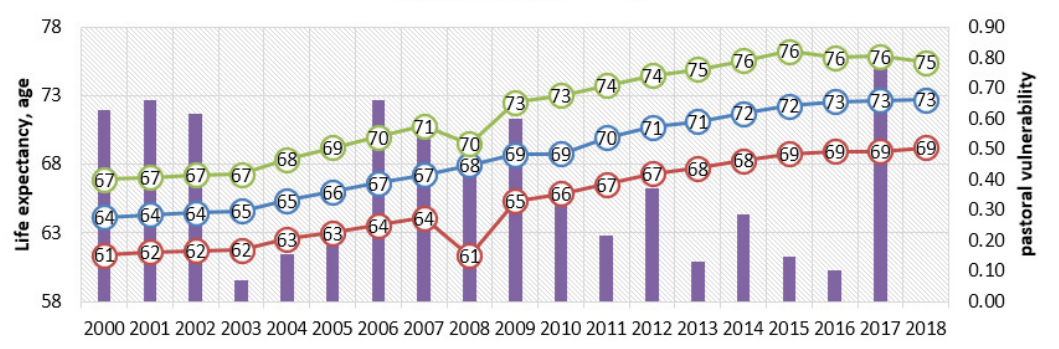

Pasture vulnerability -0 -Total -0 -Men $-0-$ Women

FIGURE 3. Difference of life expectancy for women and men in Gobi-Altai province is increasing but in Khovd province it is decreasing.

countries, herders, soum and provincial government officers, and civil societies from the two case areas and other experts from national advisory groups. During the workshop, the results of academic studies of pastoral vulnerability, socio-economic impacts, and the policy document review, as well as land degradation processes and the adaptation experiences of Chinese and Japanese team members, were presented before conducting a group discussion. Based on the research outputs and experiences of local participants, ways to resolve issues were discussed, and suitable adaptation options were identified and mapped for each soum in the Govi-Altai province (Figure 4a) and Khovd province (Figure $4 \mathrm{~b}$ ). The following general adaptation options are expected to be useful to reduce pastoral vulnerability in the case areas:

» Establish a pasture degradation inventory and monitoring system for future prevention and measurable database

» Identify areas experiencing drinking water contamination for human and groundwater depletion for livestock and biodiversity in current and future conditions

» Protect pasture degradation from steppe mice, grasshoppers and other rodents

» Improve health services for herding communities taking into consideration men's living and working conditions for their life expectancy

» Establish a herders' capacity development system through adaptive technologies and latest information

\section{CONCLUSION}

The collaborative project has enabled the participation of several regional and local governments and communities, as well as multiple academic teams; applied geospatial tools to assess climate change within collaborative processes and assess pastoral vulnerability; conducted correlation analyses of variables related to the socio-economics of pastoral societies; and evaluated policy documents and policy formulations developed through the active participation of multiple stakeholders. Pastoral vulnerability was assessed by evaluating key factors developed by the team and analyzed the relevance of factors in the socio-economic conditions of two grazing societies over the past 20 years in the selected areas of western Mongolia. The most significant variable was climate change-related drought, followed by intensive pasture use in the case areas. The study's findings reveal that pastoral vulnerability results in increased miscarriage rates in female goats, which is reflected in high correlation values of 0.5-0.8. In terms of rural communities at both provinces, differences in life expectancy for men and women are high in GobiAltai, suggesting further detailed studies and policies are needed to address the working conditions of herders impacted by climate change and their potential social service needs. The analysis of the two provinces' policy documents indicates the need for more closely aligned adaptation policies for climate change and sustainable development goals to enhance livelihood resilience in the face of climate and other variabilities. The flexibility 


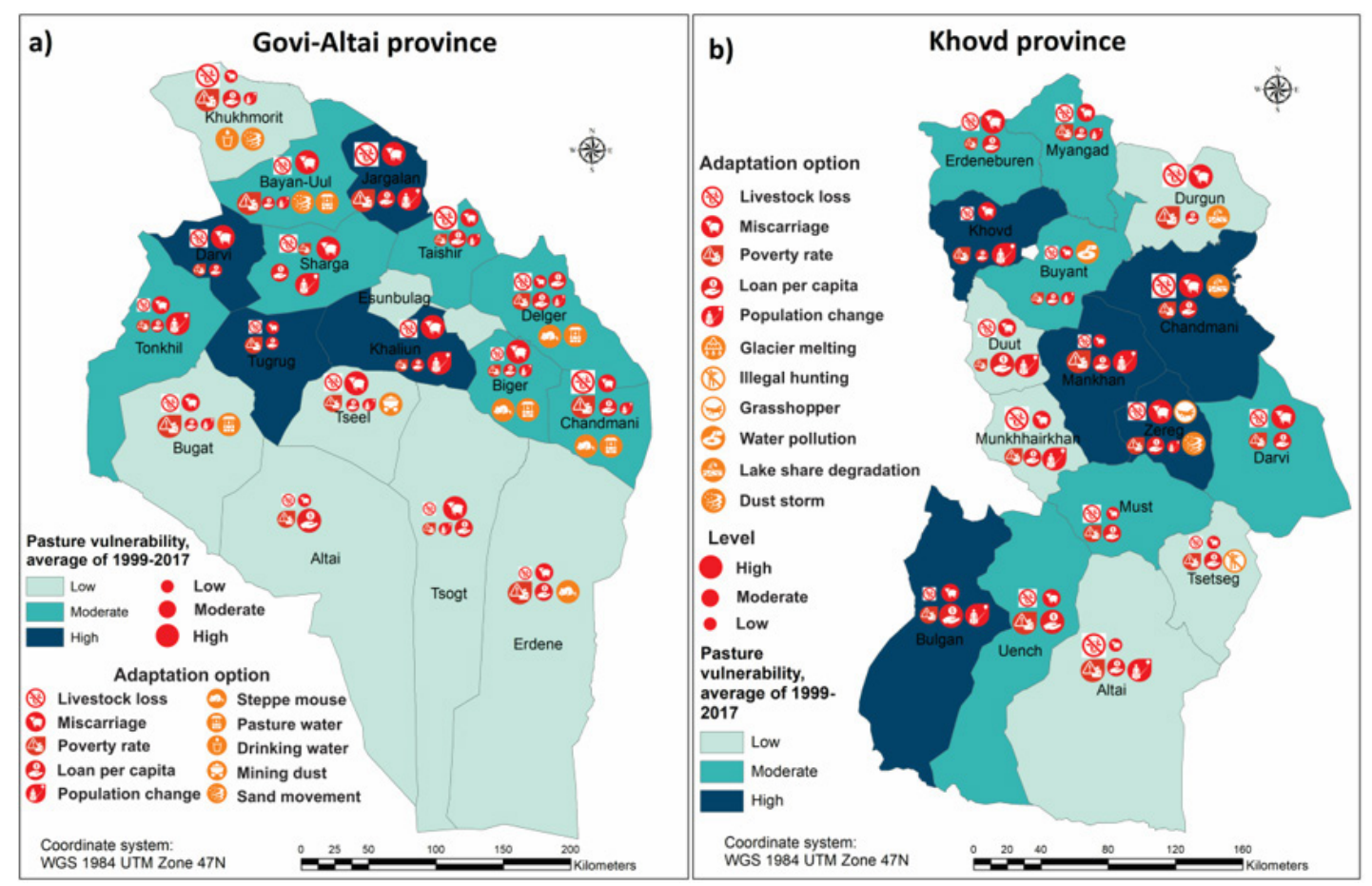

FIGURE 4. Adaptation options for reduction of pastoral vulnerability by social, ecological and economic aspects in each soum of Gobi-Altai and Khovd provinces, Mongolia.

of the local pastoral adaptation strategy process has allowed the application of geo-visualizations in placebased problem-solving and decision-making processes in a specific sociopolitical context of municipal and regional governments.

\section{ACKNOWLEDGEMENTS}

The authors gratefully acknowledge our collaborators for their contributions and offer a special thanks to local government officers from Gobi-Altai and Khovd for their assistance in identifying local issues, the herders who participated for the focus group discussions, local staff members of the Green Network in China for their in-kind support of workshop facilitation, and Dr Tuvshintogtokh and Dr Gomboluudev's team for conducting the field survey study and meteorological study. The authors would like to acknowledge the Asia-Pacific Network for Global Change Research (APN) for its financial support to this study.

\section{REFERENCES}

Adger, W. N. (2006). Vulnerability. Global Environmental Change, 16(3), 268-281. doi:10.1016/j. gloenvcha.2006.02.006

Asian Development Bank \& Ministry of Environment and Green Development (2014). Making grasslands sustainable in Mongolia herders' livelihoods and climate change. Manila: ADB.

Armitage, D. (2005). Adaptive Capacity and Community-Based Natural Resource Management.
Environmental Management, 35(6), 703-715. doi:10.1007/s00267-004-0076-z

Suvdantsetseg, B., Oba, A., Yan, W., \& Myagmarsuren, A. (2017). Early warning system for pastoral herders to reduce disaster risk by using a mobile SMS service. Proceedings of the Trans-disciplinary Research Conference: Building Resilience of Mongolian Rangelands (pp. 185-189). Ulaanbaatar: Semantic Scholar.

Batnasan, N. (2003). Freshwater issues in Mongolia. Proceeding of the National Seminar on IRBM in Mongolia (pp. 53-61). Ulaanbaatar: WWF.

Preston, B. L., Yuen, E. J., \& Westaway, R. M. (2011). Putting vulnerability to climate change on the map: A review of approaches, benefits, and risks. Sustainability Science, 6(2), 177-202. doi:10.1007/ s11625-011-0129-1

Bolortsetseg, B., Erdenetsetseg, B., \& Bat-Oyun, T. (2002). Impact of past 40 years climate change on pasture plant phenology and production. Meteorology and Hydrology of Mongolia (pp.108-114). Ulaanbaatar: Research Institute of Meteorology and Hydrology.

Togtokh, T., Altanbagana, M., Davaanyam, S., Tserenchunt, B., \& Ojima, D. (2014). Vulnerability of pastoral communities in central Mongolia to climate and land use changes. In K. Ademola, \& H. Q. Huang, Vulnerability of Land Systems in Asia (pp. 41-62). New Delhi: Wiley Press.

Togtokh, T., Altanbagana, M., Ojima, D., \& Suvdantsetseg, B. (2017). Vulnerability of pastoral social-ecological systems in Mongolia. In W. Yan, \& W. Galloway, 
Rethinking Resilience, Adaptation and Transformation in a Time of Change (pp. 73-88). London: Springer.

Davaadorj, A., Erdenetsetseg, B., Elbegjargal, N., \& Oyunjargal, L. (2017). Dzud early warning system over Mongolia. East Asia Winter Climate Outlook Forum. Tokyo: Japan Meteorological Agency.

Ojima, D., Togtokh, C., \& Altanbagana, M (2014). Vulnerability and resilience of the Mongolian pastoral social-ecological systems to multiple stressors. In K. Ademola, \& H. Q. Huang, Vulnerability of Land Systems in Asia (pp. 27-40). New Delhi: Wiley Press. doi: 10.1002/9781118854945.ch3

Fernandez-Gimenez, M., Baival, B., Batjav, B., \& Ulambayar, T. (2015). Lessons from the Dzud: Community-based rangeland management increases the adaptive capacity of Mongolian herders to winter disasters. World Development, 68, 48-65.

Gouais, L.A., \& Wach, E. (2013). A qualitative analysis of rural water sector policy documents. Water Alternatives, 6, 439-461.

Gomboluudev, V. (2019). Ecological vulnerability. Ulaanbaatar: Sod Press.

Hidalgo, B., \& Goodman, M. (2013). Multivariate or Multivariable Regression? American Journal of Public Health, 103(1), 39-40. doi:10.2105/ajph.2012.300897

Illius, A., \& Connor, T. (1999). On non-equilibrium in arid and semi-arid grazing systems. Journal of Biogeography, 29(9), 798-813.

Lane, D. M. (2019). Online statistics education: An interactive multimedia course of study. Retrieved from Onlinestatbook: http://onlinestatbook.com/2/index. html

Mongolian Academy of Sciences. (1990). Mongolian national atlas. Ulaanbaatar.

Miyasaka, T., Okuro, T., Zhao, X., \& Takeuchi, K. (2016). Classification of Land Use on Sand-Dune Topography by Object-Based Analysis, Digital Photogrammetry, and GIS Analysis in the Horqin Sandy Land, China. Environments, 3(4), 17. doi:10.3390/ environments3030017

Munkhdulam, O., Avirmed, E., Jonathan, C., \& Renchinmyadag. (2018). Assessment of landscape-ecological potential of Khovd province, Mongolia using satellite imagery and the spatial Multi-criteria Decision-Making method. Global Scientific Journals, 6 (10), 198-211.

Nandintsetseg, B., Shinoda, M., Du, C., \& Munkhjargal, E. (2018). Cold-season disasters on the Eurasian steppes: Climate-driven or man-made. Scientific Reports, 8(1). doi:10.1038/s41598-018-33046-1

Natsagdorj, L. (2009). Drought and Dzud. Ulaanbaatar. Admon Printing.

Nhuan, M. T. (2019). Synergy of climate change adaptation, mitigation and sustainable development: Lessons from Vietnam. Retrieved October 2, 2019, from National Institute for Environmental Studies Japan (NIES), from http://www.nies.go.jp/i-forum/FY2018/index. html\#tab4

NSOM. (2018). National Statistical Office of Mongolia. Retrieved June 20, 2020, from National Statistical Office of Mongolia: 1212.mn

O'Brien, K., Leichenkob, R., Kelkar, U., Venema, H., Aandahl, G., Tompkins, H., ... \& West, J. (2004). Mapping vulnerability to multiple stressors: Climate change and globalization in India. Global Environmental Change, 14, 303-313.

Okuro, T. (2019). Restoration and reconstrustion of sustainable land management systems under highly variable environments. Proceeding of the 2nd Workshop on Social-Ecological Systems Governance for Sustainability (pp. 14-15). Ulaanbaatar: Sod Press.

Reynolds, J., Smith, D., Lambin, E., Turner, B., Mortimore, M., Batterbury, S., ... \& Huber-Sannwald, E. (2007). Global desertification: building a science for dryland development. Science, 316(5826), 847-851.

Shinoda, M., Nandintsetseg, B., \& Erdenetsetseg, B. (2018). Contributions of multiple climate hazards and overgrazing to the $2009 / 2010$ winter disaster in Mongolia. Natural Hazards, 92(1) 109-126.

Troy, S. (2015). Drought and extreme climate stress on human-environment systems in the Gobi desert Mongolia. In K. Ademola, \& Q. H. He, Vulnerability of Land Systems in Asia (pp. 11-22). New Delhi: Wiley.

Tserendash, S., \& Bilegt, T. (2017). Mongolian Environment: Pasture, and soil use and protection. Ulaanbaatar. Mongolian Academy of Sciences.

Turner, B. L., Kasperson, R. E., Matson, P. A., McCarthy, J. J., Corell, R. W., Christensen, L., ... Schiller, A. (2003). A framework for vulnerability analysis in sustainability science. Proceedings of the National Academy of Sciences, 100(14), 8074-8079. doi:10.1073/ pnas. 1231335100

Weier, J., \& Herring, D. (2000, August 30). Measuring vegetation (NDVI \& EVI). NASA Earth Observatory. 